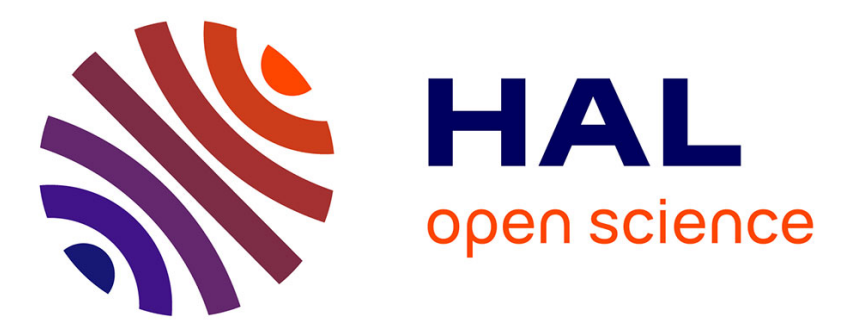

\title{
Integrating geospatial tools and a crop simulation model to understand spatial and temporal variability of cereals in Scotland
}

D. Cammarano, J. Holland, B. Basso, F. Fontana, T. Murgia, C. Lange, J. Taylor, D. Ronga

\section{To cite this version:}

D. Cammarano, J. Holland, B. Basso, F. Fontana, T. Murgia, et al.. Integrating geospatial tools and a crop simulation model to understand spatial and temporal variability of cereals in Scotland. 12th European Conference on Precision Agriculture, ECPA 2019, Jul 2019, Montpellier, France. pp.29-35, 10.3920/978-90-8686-888-9_2 . hal-02609773

\section{HAL Id: hal-02609773 https://hal.inrae.fr/hal-02609773}

Submitted on 16 May 2020

HAL is a multi-disciplinary open access archive for the deposit and dissemination of scientific research documents, whether they are published or not. The documents may come from teaching and research institutions in France or abroad, or from public or private research centers.
L'archive ouverte pluridisciplinaire HAL, est destinée au dépôt et à la diffusion de documents scientifiques de niveau recherche, publiés ou non, émanant des établissements d'enseignement et de recherche français ou étrangers, des laboratoires publics ou privés. 


\title{
Integrating geospatial tools and a crop simulation model to understand spatial and temporal variability of cereals in Scotland
}

\author{
D. Cammarano ${ }^{1}$, J. Holland ${ }^{1}$, B. Basso ${ }^{2}$, F. Fontana ${ }^{3}$, T. Murgia ${ }^{4}$, C. Lange ${ }^{5,1}$, J. Taylor ${ }^{6}$, \\ D. Ronga ${ }^{7}, 1$ \\ ${ }^{1}$ James Hutton Institute, Errol Road, DD25BQ, U.K. \\ ${ }^{2}$ Michigan State University, 307 Natural Science, East Lansing, USA, \\ ${ }^{3}$ Universita' della Tuscia, Via S Maria in Gradi 4, 01100 Viterbo, Italy \\ ${ }^{4}$ Universita' di Sassari, Via Enrico de Nicola 7, Sassari, Italy \\ ${ }^{5}$ Ecole d'Ingénieurs de Purpan, 75 voie du TOEC, 31076 Tolouse, France \\ ${ }^{6}$ ITAP, Irstea, University of Montpellier, Montpellier France, 34196, \\ ${ }^{7}$ Universita' di Modena e Reggio Emilia, Via Università 4, 41121 Modena, Italy \\ davide.cammarano@hutton.ac.uk
}

\begin{abstract}
The objectives of this study were to: a) quantify the factors causing spatial variability, and b) design a proof of a concept for a support system that considers the impacts of temporal variability. The subdivision of a field based on six years of spatial yield data identified areas with different levels of stable and unstable zones. Overall, in the 0.0$0.30 \mathrm{~m}$, the soil had between 40 to $60 \%$ across all the zones, while at depth, the clay content was about $20 \%$ and sand content 30 to $40 \%$. The growing season rainfall for the period 1983-2018 was highly variable, ranging from 152 to $570 \mathrm{~mm}$. The support system showed that there was a general trend where higher growing season rainfall (e.g. $566 \mathrm{~mm}$ ) corresponded to higher yields, but this meant lower soil nitrogen content at harvest. However, the nitrogen leaching was not always lower and ranged between 20 to $70 \mathrm{~kg} \mathrm{~N} \mathrm{ha}{ }^{-1}$. Results of this study will enable the development of an agronomic sitespecific $\mathrm{N}$ management that would maximize the farm's net income and minimize the environmental footprint.
\end{abstract}

Keywords: Spatial variability, temporal variability, barley, crop growth model, interannual variability.

\section{Introduction}

Nowadays, the world is facing the biggest challenge of producing more food on the same or less land, and by reducing its environmental footprint while keeping farming profitable (Cammarano et al, 2016). Precision agriculture (PA) offers a unique opportunity to achieve such trade-off, but its adoption for agricultural management has been slower than expected due to technological and socio-economic challenges (Miao et al, 2018). The amount of any agricultural input applied (e.g. fertiliser) may be varied spatially within the field and temporally between years. In fact, for the same field, determination of the optimal amount of any agronomic input should consider sitespecific soil properties, current seasonal crop growing conditions and interactions therein (Basso et al, 2011). Spatial variability can be assessed routinely with a variety of tools (e.g. remote sensing, soil sensing) and the overlay of many thematic maps, such as for soil and crop yield, to divide the field into uniform management zones (Miao et al, 2006). Several methods have been proposed to define such zones (Nawar et al, 2017). 
However, an important step in taking the right agronomic decision is to quantify which factors cause the spatial and temporal variability in the field; with the latter component not receiving enough attention (McBratney et al, 2005). Crop simulation models (CSM) can be used to consider the inter-annual weather impact on the soil-plant-atmosphere interactions (Jones et al, 2003). They seek to simulate the effects and temporal interactions of water and nitrogen on crop growth as affected by weather and agronomic management (Jones et al, 2003). They have been used in a variety of cropping systems and environmental conditions; and to quantify the temporal stability of management zones (Basso et al, 2001; Koo and Rivington, 2005). Nitrate leaching from agricultural land is a consequence of over fertilization and the difficulties in matching crop demand with soil supply (Basso et al, 2011). The European Union addressed the issue by defining nitrate vulnerable zones, which are areas where pollution of groundwater with nitrates is high (EC, 2000). In Scotland, farmers comply with such regulations by capping the amount and timing of $\mathrm{N}$ applications (STI, 2008). The objectives of this study were to: a) quantify the factors causing spatial variability, and b) use this information to design a proof of a concept for a support system that would consider the impacts of temporal variability.

\section{Materials and methods}

Measurements were taken on a commercial field (11 ha; $56^{\circ} 33^{\prime} \mathrm{N}^{\circ} 16^{\prime} \mathrm{W} ; 50 \mathrm{~m}$ a.s.1.) in Scotland. The soil was classified as loam according to the USDA. Spring barley (cv. Concerto) was sown on $12^{\text {th }}$ of April 2018 at 350 plants $\mathrm{m}^{-2}$. In each zone (see Fig. 1), a transect of points was set and the soil was sampled at three depths (0$0.30 ; 0.30-0.60 ; 0.60-0.90 \mathrm{~m})$ one month before sowing. Samples were analysed for bulk density, water retention characteristic, texture, mineral $\mathrm{N}, \mathrm{P}, \mathrm{K}$, cation exchange capacity (CEC), organic matter and water content. Fertilization was uniformly distributed after emergence on the $1^{\text {st }}$ of May 2018. Ammonium nitrate was applied for a total of $120 \mathrm{~kg} \mathrm{~N} \mathrm{ha}^{-1}$. Soil samples (for mineral $\mathrm{N}$ and soil water content), crop samples (for biomass and nitrogen content) and unmanned aerial vehicle (UAV) images were collected one day before sowing, three weeks after fertilization (23 May), at flowering (20 Jun) and harvest (16 Aug). UAV data collected three weeks after fertilization was the only image used in this study.

The use of six consecutive years of winter/spring wheat and barley maps allowed the delineation of zones. The yield maps were generated by a combine harvester owned by the farmer. To define the zone, the approach developed by Maestrini and Basso (2018a, b) was used. Three stable zones were defined as High Stable (HYZ), Medium Stable (MYZ) and Low Stable (LYZ), while the unstable zones were named (UYZ) Unstable (Fig. 1a).

The Decision Support System for Agrotechnology Transfer (DSSAT) v.4.7 was used as the CSM (Jones et al, 2003). For this study, measured information of soil properties, initial soil water and soil $\mathrm{N}$ content were available. The crop coefficient for the cultivar Concerto was obtained by calibrating phenology, growth and yield on crop variety trials and on "potential yield" experiments (irrigated and fertilized experiments). The calibrated model for this cultivar was evaluated on independent datasets across 4 experimental sites and 10 farms across Scotland (results not shown). The model was run using 36 years of historical weather data. Weather data for 2018 was available from the on-farm weather station while the historical 1980-2017 data were obtained from the 
NASA-Power website (power.larc.nasa.gov). Following the approach described in Basso et al. (2001; 2011), the DSSAT model was run for different yield stability zones with incremental $\mathrm{N}$ amounts $(0 \mathrm{~N}, 60 \mathrm{~N}, 120 \mathrm{~N}$-farmers' practice, $180 \mathrm{~N})$. The model simulated yield and cumulative $\mathrm{N}$ leaching from sowing to harvest, and total soil $\mathrm{N}$ at harvest. The cumulative probability function of simulated yield and cumulative $\mathrm{N}$ leaching was calculated following the approach of Wallach et al. (2013). The coefficient of variation $(\mathrm{CV})$ was used to quantify the amount of inter-annual variability for the simulated yield and the $\mathrm{N}$ leaching.

\section{Results}

While the HYZ was mostly concentrated in one portion of the field, the UYZ showed a spatial pattern being present at the edges of the field and the mid-lower portion (Fig. 1a). The subsequent UAV image (NDVI), collected on the $23^{\text {rd }}$ of May 2018 (22 days after $\mathrm{N}$ fertilization), showed how crop growth patterns corresponded with the zones defined in Fig. 1a. The coloured points on Fig. 1b indicate where samples were taken in each zone (Fig. 1b).

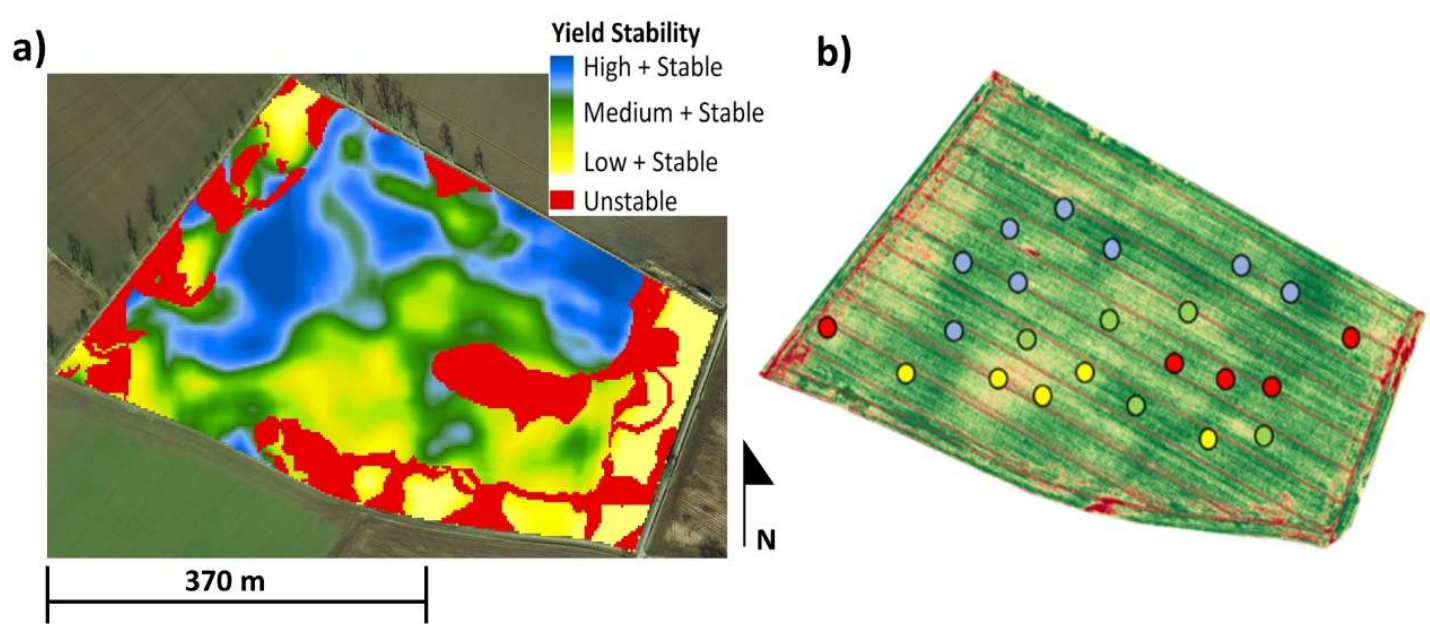

Figure 1. Spatial patterns of the (a) zones identified by overlaying six years of yield maps; and (b) drone image collected on the $23^{\text {rd }}$ of May and the corresponding points sampled in the field.

At $0-0.30 \mathrm{~m}$, most of the points were classified as loam soils according to the USDA (Fig. 2). At $0.30-0.60 \mathrm{~m}$ and at $0.60-0.90 \mathrm{~m}$, the different zones had texture that ranged from clay to sandy loam (Fig. 2). Overall, in the $0.0-0.30 \mathrm{~m}$, the soil had between 40 to $60 \%$ of sand and less than $20 \%$ of clay across all the zones, while at depth, the clay content was about $20 \%$ and sand content 30 to $40 \%$ (Fig. 2). The LYZ and UYZ zones had the greatest variability in soil texture (Fig. 2). 


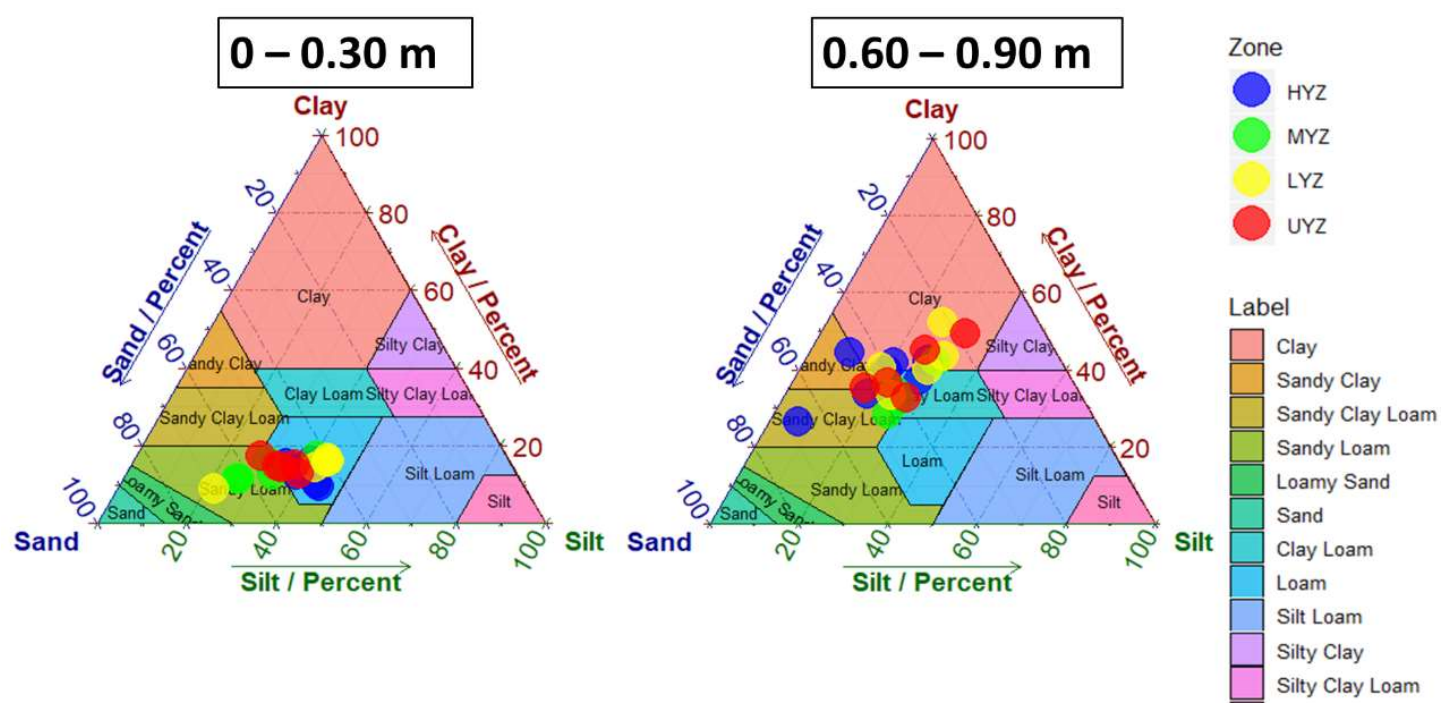

Figure 2. Soil texture triangle at two different depths, the coloured points represent the sampling taken at each zone.

Total growing season rainfall (Apr-Aug) was $170 \mathrm{~mm}$ with most of the precipitation occurring before sowing and towards the end of the growing season (Fig. 3). The plant available soil water content (PAWC) for the soil profile decreased for the period AprilMay due to $50 \%$ less rain with respect to the long-term average of $76 \mathrm{~mm}$ for the same period (Fig. 3a). The HYZ showed PAWC value of $173 \mathrm{~mm}$, while the MYZ, LYZ and UYZ showed values of 163, 170 and $164 \mathrm{~mm}$, respectively (Fig. 3a).

The total soil nitrogen content $(\mathrm{N})$ increased (especially in the UYZ) between sowing (April $12^{\text {th }}$ ) and the $22^{\text {nd }}$ of May, a time in which fertiliser was added (May $1^{\text {st }}$ ) and no signficant rainfall was recorded (Fig. 3b). The UYZ had the highest amount of soil $\mathrm{N}$ during the whole growing season but, by harvest, a large amount was lost and it decreased to a total of $70 \mathrm{~kg} \mathrm{~N} \mathrm{ha}^{-1}$ (Fig. 3b).
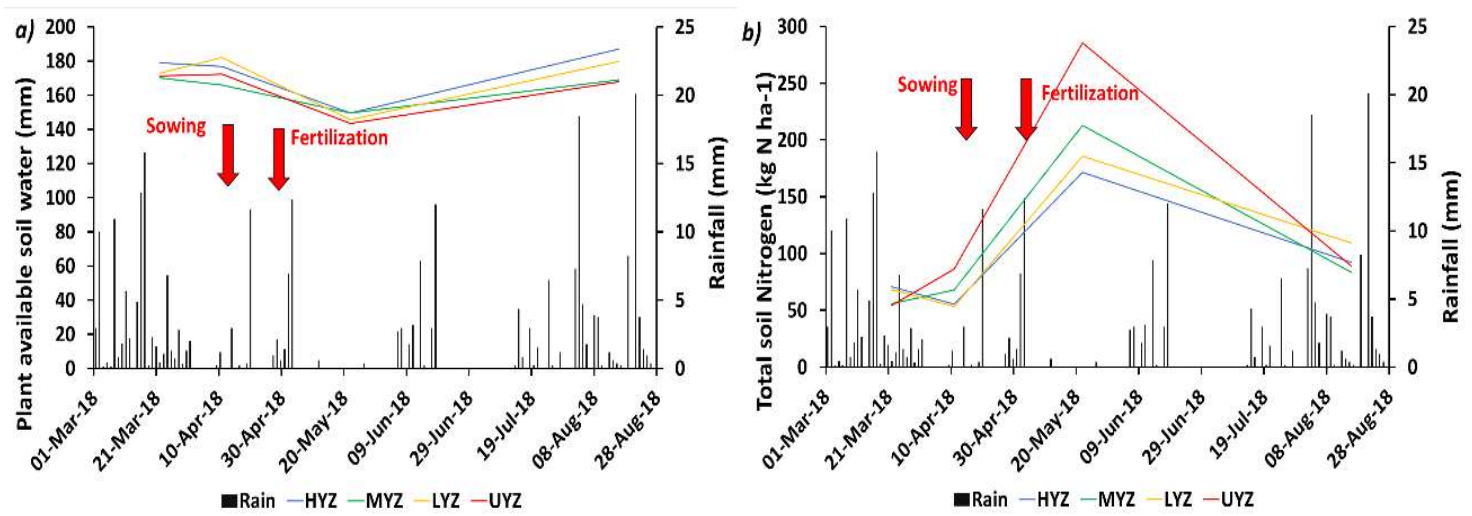

Figure 3. Growing season rainfall (black bar; secondary Y-axis) and (left) plant available soil water content and (right) total soil nitrogen for the different yield stability zones; High yielding zone (HYZ) (red line), medium yielding zone (MYZ) (green line), low yielding zone (LYZ) (yellow line) and unstable yielding zone (UYZ) (red line). The thick red lines indicate the time of sowing (12 April 2018) and $N$ fertilization (1 May 2018). 
The growing season rainfall for the period 1983-2018 was highly variable, ranging from 152 to $570 \mathrm{~mm}$, while growing season minimum and maximum temperatures did not show high inter-annual variability (Fig. 4a). The results of the simulations were presented as boxplots and showed that the HYZ was higher yielding than the other zones when the $\mathrm{N}$ fertilizer was between 0 and $120 \mathrm{~N}$ (Fig. 4b); at $180 \mathrm{~N}$ the differences among the zones was minimal with an overall simulated yield of about $7500 \mathrm{~kg} \mathrm{DM} \mathrm{ha}^{-}$ 1. The inter-annual variability (1980-2018) of simulated yield and N leaching was also analysed in term of $\mathrm{CV}$ and is shown in Figure 4c. Overall, the simulated yield had a lower CV than $\mathrm{N}$ leaching with an overall 14\% for yield and 33\% for $\mathrm{N}$ leaching (Fig. $4 c)$. Figure $4 d$ shows the relationship between the marginal yield increase per unit $\mathrm{N}$ applied versus the simulated $\mathrm{N}$ leaching. There was a higher marginal yield increase when fertilizer was applied and as the amount increased, the marginal yield return diminished. On the other hand, the amount of $\mathrm{N}$ leached increased with applied $\mathrm{N}$ for each zone, but it is more evident for the LYZ and UYZ (Fig. 4d).
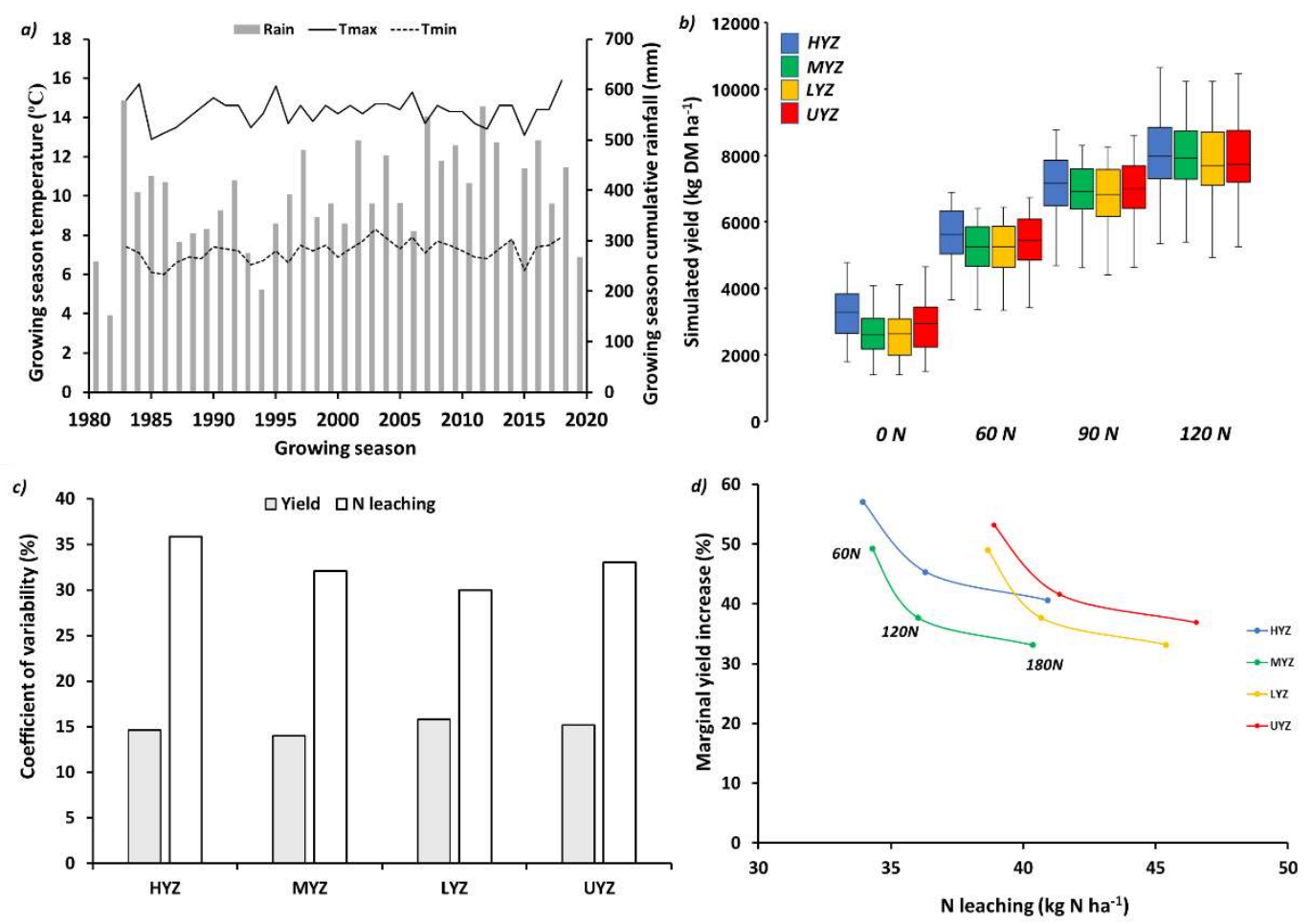

Figure 4. (a) values of cumulated growing season rainfall (grey bars), growing season maximum (full black line) and minimum (dotted black line) temperature; distribution of (b) simulated yields at $0 \mathrm{~N}, 60 \mathrm{~N}, 120 \mathrm{~N}$ and $120 \mathrm{~N}$ (c) coefficient of variation for the simulated yield (grey bars) and the N leaching (white bars) for each zone; and (d) relationship between marginal yield increase per unit of nitrogen applied and simulated $\mathrm{N}$ leaching.

The relationship between the growing season rainfall, $\mathrm{N}$ leaching, total $\mathrm{N}$ in the soil at harvest, and grain yield is shown in Figure 5. Overall, there was a general trend where higher growing season rainfall (e.g. $566 \mathrm{~mm}$ ) corresponded to higher yields, but this meant lower soil $\mathrm{N}$ content at harvest. However, the $\mathrm{N}$ leaching was not always lower and ranged between 20 to $70 \mathrm{~kg} \mathrm{~N}$ ha $^{-1}$ (Fig. 5). 
At lower growing season rainfall (268 mm), the simulated yield was 3964, 3872, 3645, and $3786 \mathrm{~kg} \mathrm{DM} \mathrm{ha}^{-1}$ for the HYZ, MYZ, LYZ and UYZ, respectively (Fig. 5). In this case, the $\mathrm{N}$ leaching was similar across the different zones (a mean of $25 \mathrm{~kg} \mathrm{~N} \mathrm{ha}^{-1}$ ) but the residual $\mathrm{N}$ at harvest was different, with $72 \mathrm{~kg} \mathrm{~N} \mathrm{ha}^{-1}$ for the HYZ, $58 \mathrm{~kg} \mathrm{~N} \mathrm{ha}^{-1}$ for the MYZ, $63 \mathrm{~kg} \mathrm{~N} \mathrm{ha}^{-1}$ for the LYZ and $66 \mathrm{~kg} \mathrm{~N} \mathrm{ha}^{-1}$ for the UYZ (Fig. 5). When the growing season rainfall was $500 \mathrm{~mm}$, the HYZ showed a simulated yield of $8184 \mathrm{~kg}$ DM ha ${ }^{-1}$, while the MYZ, LYZ and UYZ were 7976, 7961 and $8110 \mathrm{~kg} \mathrm{DM} \mathrm{ha}^{-1}$ (Fig. 5). The $\mathrm{N}$ leaching was 38, 37, 42 and $43 \mathrm{~kg} \mathrm{~N} \mathrm{ha}^{-1}$, for the HYZ, MYZ, LYZ and UYZ, respectively (Fig. 5), but the residual soil $\mathrm{N}$ was about $13 \mathrm{~kg} \mathrm{~N} \mathrm{ha}^{-1}$ for all zones (Fig. $5)$.
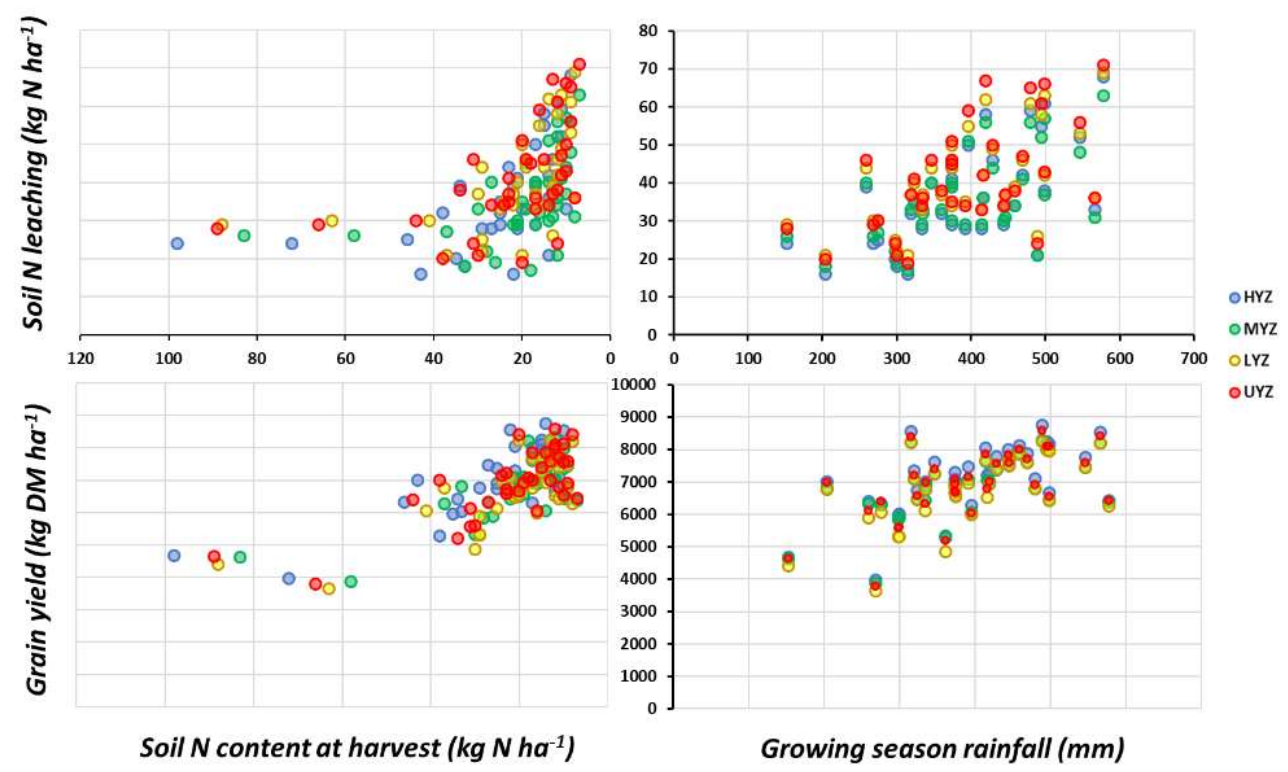

Figure 5. relationship between simulated $\mathrm{N}$ leaching, growing season rainfall, soil $\mathrm{N}$ content at harvest, and grain yield for the HYZ (blue dots), the MYZ (green dots), LYZ (yellow dots) and UYZ (red dots).

\section{Discussion}

There was a high degree of spatial variability within the field. However, the overlay of six years of yield maps allowed for discriminating stable and unstable yield zones in the field. The spatial variability of crop growing in the field was also confirmed by a UAV image taken 21 days after fertilization. The HYZ showed better growing conditions than other zones (Fig. 1). Soil texture at depth below $0.30 \mathrm{~m}$ had an impact with respect to the water and $\mathrm{N}$ distribution, and bulk density results confirmed that below $0.40 \mathrm{~m}$, the LYZ had very compact layers (with values of $1.8 \mathrm{~g} \mathrm{~cm}^{-3}$; data not shown) while other zones had a lower bulk density (below $1.6 \mathrm{~g} \mathrm{~cm}^{-3}$ ). This spatial pattern influenced the soil mineral $\mathrm{N}$ and soil water distribution and plant uptake where the UYZ tends to accumulate more $\mathrm{N}$ in the whole soil profile than other zones. The use of long-term weather data with a CSM demonstrated how the inter-annual variability affects crop growth and the environmental footprint of fertilization management. While 2018 was a very "dry" season for Scottish growing conditions, other years have shown similar rainfall patterns with very "dry" growing seasons (e.g. 1982 or 1994, Fig. 4a). Results of this study regarding the impacts of growing season rainfall agree with the findings of 
Basso et al. (2012) conducted in a different environment. This indicates that even in such northern latitudes, growing season rainfall is an important determinant of grain yield for spring barley. The zones tended to respond differently to the inter-annual variability. However, the long-term simulations showed that there was a consistency between the map of the zones and the simulated yield. The HYZ was always higher yielding, even in drier years, while the UYZ was not stable high or low but tended to "flip" between years. The HYZ was very responsive to rainfall and showed lower $\mathrm{N}$ leaching levels and low soil total $\mathrm{N}$ at harvest at higher rainfall amounts with respect to the other zones (Fig. 5). It is interesting to notice that the simulated soil $\mathrm{N}$ at harvest for the dry years in each zone is in line with the observed data collected in 2018. For all the low rainfall growing seasons, there was low $\mathrm{N}$ leaching amount, and a high soil total $\mathrm{N}$ at harvest. This has important implications in managing $\mathrm{N}$ fertilization because, in the UYZ and LYZ, extra care should be taken in assigning a given amount of site-specific N. In fact, Figure $4 \mathrm{~d}$ showed that these zones, fertilized with $120 \mathrm{~kg} \mathrm{~N}^{-1}$ like the whole field, are very prone to $\mathrm{N}$ leaching and, with respect to the EC regulations on Nitrate Vulnerable Zones, 60 to $90 \mathrm{~kg} \mathrm{~N} \mathrm{ha}^{-1}$ would be the amount to apply (Fig. 4d). Basso et al. (2011) defined tactical and strategic fertilization management amounts in each zone of a field using a CSM as decision support system. An integration of modelling results and on-farm experimentation will be planned for the next growing season (2019) with the aim of improving the efficacy of site-specific $\mathrm{N}$ fertilization.

\section{Conclusions}

The subdivision of the field into zones based on historic yields showed zones with different levels of yield potential and stability. This included an unstable zone where the historical yield tended to change from high to low values between years. The classification of yield into yield stability zones was confirmed by a subsequent UAV image, taken 20 days after $\mathrm{N}$ fertilization, and a crop simulation model run with longterm historical weather data. These results indicated the robustness of a yield-based zoning approach. Growing season rainfall, soil texture below $0.30 \mathrm{~m}$ and soil bulk density impacted the distribution of soil water and $\mathrm{N}$ and the crop growing conditions in each zone. By considering the spatial and temporal variability of each zone, an agronomic site-specific $\mathrm{N}$ management could be better tailored for each zone in order to maximize the farm's net income and minimize the environmental footprint. Results of this study showed that at $120 \mathrm{~kg} \mathrm{~N} \mathrm{ha}^{-1}$ the simulated yield was higher. However, the marginal yield return per $\mathrm{N}$ applied tended to be lower and accompanied by a higher $\mathrm{N}$ leaching.

\section{Acknowledgements}

This project was funded by the Scottish Government Seedcorn Fund (18.12). We thank the Reid family for the availability in using their farm.

\section{References}

Basso, B., Fiorentino, C., Cammarano, D., Cafiero, G., Dardanelli, J., 2012. Analysis of rainfall distribution on spatial and temporal patterns of wheat yield in Mediterranean environment. European Journal of Agronomy 41 52-65. 
Basso, B., Ritchie, J.T., Cammarano, D., Sartori, L., 2011. A strategic and tactical management approach to select optimal $\mathrm{N}$ fertilizer rates for wheat in a spatially variable field. European Journal of Agronomy 35, 215-222.

Basso, B., Ritchie, J.T., Grace, Pierce, F.J., Braga, R.P., Jones, J.W., 2001. Spatial validation of crop models for precision agriculture. Agricultural Systems 68, 97112.

Cammarano, D., Roetter, R.P., Asseng, S., Ewert, F., Wallach, D., Martre, P., et al., 2016. Uncertainty of wheat water use: Simulated patterns and sensitivity to temperature and $\mathrm{CO}_{2}$. Field Crop Research 198, 80-92.

EC, 2000. Council directive of 23th October 2000 establishing a framework for Community action in the field of water policy (2000/60/EC). Official Journal of the European Union 22/12/2000 L327/1 to 73.

Jones, J.W., Hoogenboom, G., Porter, C.H., Boote, K.J., Batchelor, W.D., Hunt, L.A., et al., 2003. The DSSAT cropping system model. European Journal of Agronomy 18, 235-265.

Koo, J., Rivington, M., 2005. Report on the Meta-analysis of Crop Modelling for Climate Change and Food Security Survey Climate Change. Agriculture and Food Security (CCAGS), Challenge Program, Denmark (available at www.ccafs.cgiar.org).

Maestrini, B., Basso, B., 2018a. Predicting spatial patterns of within-field crop yield variability. Field Crops Research 219, 106-112.

Maestrini, B., Basso, B., 2018b. Drivers of within-field spatial and temporal variability of crop yield across the US Midwest. Scientific Reports 8, 14833. doi: 10.1038/s41598-018-32779-3

McBratney, A., Whelan, b., Ancev, T., 2005. Future directions of precision agriculture. Precision Agriculture 6, 7-23.

Miao, Y., Mulla, D., Robert, P.C., 2018. An integrated approach to site-specific management zone delineation. Frontiers of Agricultural Science and Engineering. 5, 432-441.

Miao, Y., Mulla, D.J., Batchelor, W.D., Paz, J.O., Robert, P.C., Wiebers, M., 2006. Evaluating management zone optimal nitrogen rates with a crop growth model. Agronomy Journal 98, 545-553.

Nawar, S., Corstanje, R., Halcro, G., Mulla, D., Mouazen, A.M., 2017. Delineation of Soil Management Zones for Variable Rate Fertilization: A review. Advances in Agronomy 143,175-245.

Scottish Statutory Instruments (STI), 2008. The Action Programme for Nitrate Vulnerable Zones (Scotland) Regulation. Scottish Government, Edinburgh (www2.gov.scot/Publications/2012/03/4576)

Wallach, D., Makowski, D., Jones, J.W., Brun, F., 2013. Working with dynamic crop models: methods, tools, and examples for agriculture and environment. Amsterdam, the Netherlands: Elsevier Science, 504 pp. 